\title{
Education, Science and Technology in Mexico: Challenges for Innovation
}

\author{
Fernando Carlos Gómez-Merino ${ }^{1}$, Libia Iris Trejo-Téllez ${ }^{2}$, María Esther Méndez-Cadena ${ }^{3} \&$ Aleida Selene \\ Hernández-Cázares ${ }^{1}$ \\ ${ }^{1}$ Colegio de Postgraduados Campus Córdoba, Carretera Córdoba-Veracruz km 348, Manuel León, Amatlán de \\ los Reyes, Veracruz, C. P. 94946, Mexico \\ ${ }^{2}$ Colegio de Postgraduados Campus Montecillo, Carretera México-Texcoco km 36.5, Montecillo, Texcoco, State \\ of Mexico, C. P. 56230, Mexico \\ ${ }^{3}$ Colegio de Postgraduados Campus Puebla, Carretera Federal México-Puebla km 125.5, Cholula, Puebla, C. P. \\ 72760, Mexico \\ Correspondence: Fernando Carlos Gómez-Merino, Colegio de Postgraduados Campus Córdoba, Carretera \\ Córdoba-Veracruz km 348, Manuel León, Amatlán de los Reyes, Veracruz, C. P. 94946 Mexico. Tel: \\ 52-271-716-6000, E-mail: fernandg@colpos.mx
}

Received: December 2, $2016 \quad$ Accepted: January 13, $2017 \quad$ Online Published: April 29, 2017

doi:10.5539/ies.v10n5p115 URL: https://doi.org/10.5539/ies.v10n5p115

\begin{abstract}
The innovation process is founded on a high-quality education system at all levels, which trains scientists and technologists capable of generating innovations. Education is the most decisive factor in human development, yet in Mexico current statistics reveal a critical situation at every educational level, as only 1 out of every 10 children entering elementary school obtains a university degree, and less than $0.01 \%$ of the population holds a doctoral degree. In addition, international tests such as the Programme for International Student Assessment (PISA) reflect the low educational performance of Mexican students in several subject areas. The deficiencies found in the national education system negatively impact innovation indicators. Although there have been major initiatives to reverse underperformance in education, science, technology and innovation (STI), the country has actually seen its global competitiveness ranking fall from $55^{\text {th }}$ in 2013 to $57^{\text {th }}$ in 2015 , and structural reforms in education, science and technology proposed since 2012 have still not been successfully implemented. This paper analyses the current status of the education and STI systems in Mexico and sets out some strategies to improve public policies to profit from the great competitive advantages that Mexico has as an emerging economy, with about 52 million economically active people and great untapped potential if innovations policies are implemented successfully.
\end{abstract}

Keywords: education system, innovation management, public policies, R\&D

\section{Introduction}

Education quality, scientific research and technological development play a crucial role in innovation. In turn, innovation is a key factor enabling nations to attain sustainable growth and development, thereby helping to reduce the economic and political inequalities of their citizens and achieve social well-being and peace.

In recent decades, through various public policies, several governments around the world have been keen to achieve competitive advantages in their economies, enabling them to attain sustainable economic growth, comparable or greater than that of their peers, and these strategies have been based on innovation.

According to a recent analysis by the United Nations Development Programme (UNDP, 2014), education is the main driving force behind human development in Mexico. A high human development index (HDI) implies that people are in a better position to take advantage of the benefits offered by innovation, and have a higher level of health, education and other basic services, as well as better wages, which leads to greater wellness.

Given the importance of education as a pillar of human development and innovation, the important elements of Mexico's National Educational System (NES) are described below. Furthermore, we analyze the STI system, the current status of innovation indicators and the major challenges for innovation in the country, while proposing some strategies to improve public policies aimed at fostering innovation. 


\section{The Mexican National Educational System}

Countries with more advanced economies have a solid and efficient education system, enabling them to create wealth and maintain high levels of social security and peace, through the articulation of knowledge value chains. This articulation begins with strengthening the education system and the skills to create new knowledge and technologies to innovate, and culminates in the creation of wealth and well-paying jobs. These advances, in turn, generate general well-being, governance, tax revenues and social security.

Thus, education is part of the foundation of innovation, and better-educated nations are more likely to generate innovations that positively transform their production systems.

According to the General Education Act (GEA; Cámara de Diputados, 2014a), three educational modes are recognized in Mexico: formal school, non-school and mixed. In terms of the formal school option, the NES in Mexico comprises three types of education: basic (BE), intermediate (IE) and higher (HE). In each education type there are several instructional levels, and in some of these, various types of services (Table 1) (Secretaría de Educación Pública [SEP], 2012; Instituto Nacional para la Evaluación de la Educación [INEE], 2014).

Table 1. National Education System in Mexico, with three types of school education offered: basic, intermediate and higher

\begin{tabular}{|c|c|c|c|}
\hline Type of education & Educational level & Type of services or Educational model & Duration in years \\
\hline \multirow{9}{*}{ Basic education } & \multirow{3}{*}{ Preschool } & General & \multirow{3}{*}{3} \\
\hline & & Community courses & \\
\hline & & Indigenous & \\
\hline & \multirow{3}{*}{ Primary } & General & \multirow{3}{*}{6} \\
\hline & & Community courses & \\
\hline & & Indigenous & \\
\hline & \multirow{3}{*}{ Junior secondary } & General & \multirow{3}{*}{3} \\
\hline & & Technical & \\
\hline & & Telesecundaria & \\
\hline \multirow{3}{*}{ Intermediate education } & Career technical & CET, Cecyte, Conalep and others & \multirow{3}{*}{3} \\
\hline & \multirow{2}{*}{ High school } & General & \\
\hline & & Technological & \\
\hline \multirow{8}{*}{ Higher education } & \multirow{2}{*}{ Higher technical } & Professional technical & \multirow{5}{*}{3 to 5} \\
\hline & & Others & \\
\hline & \multirow{3}{*}{ Bachelor's degree } & Teacher training & \\
\hline & & Technological & \\
\hline & & University & \\
\hline & \multirow{3}{*}{ Postgraduate } & Specialty & \multirow{3}{*}{1 to 5} \\
\hline & & Master's degree & \\
\hline & & Ph.D. & \\
\hline
\end{tabular}

Source: SEP (2012); INEE (2014).

Basic education (BE) is compulsory and consists of three levels: preschool, elementary and junior secondary. Intermediate education (IE) comprises the high school or equivalent levels, as well as career technical education and its equivalents. The decree making this educational level compulsory was signed into law in 2012, and it began being phased in during the 2012/2013 cycle in order to achieve full coverage in the 2021/2022 cycle. Importantly, Mexico has developed a better system of vocational education and training for IE, which has dramatically increased its impact in the last decade (Cáceres-Reebs \& Schneider, 2013). Vocational education and training that provides a combination of theory and company-based training is considered to be a successful strategy for training skilled workers in line with economic needs. Higher education (HE) is the third NES education type, and in it professionals are trained in all branches of knowledge; it is imparted after high school or its equivalent, and is composed of bachelor's, specialty, master's and doctoral levels, as well as by end options prior to the conclusion of a bachelor's degree. It also includes teacher training for all levels and specialties. Therefore, according to the recent education reform (Cámara de Diputados \& INEE, 2015), the current compulsory State education extends from preschool to the IE. 
In addition to the formal school option, the NES recognizes the non-school and mixed education options. The non-school system refers to education services aimed at populations with specific characteristics requiring differentiated, specialized or flexible attention. This set of services is also called extracurricular and includes early education (infant and maternal), special education (the disabled and the gifted), open or semi-school systems (high school, technical professional, undergraduate and graduate), adult education (literacy, basic education, non-formal job training and cultural missions), indigenous extracurricular education and job training.

The mixed mode is the combination of the formal school and non-school modes, and is characterized by its flexibility to study subjects or modules that make up the curriculum, either in person or by distance learning.

After the education system of the United States with nearly 76 million students and Brazil with close to 54 million, the Mexican NES has the third largest number of students in the Americas (Banco Interamericano de Desarrollo [BID], 2012). For the 2013-2014 school year, the total student population of Mexico (from preschool to graduate school) in the formal school mode was 35.7 million students (equivalent to $30 \%$ of the national population), with close to 2 million teachers (Table 2) (Instituto Nacional de Estadística y Geografía [INEGI], 2012; INEE, 2014; Presidencia de la República, 2014).

Table 2. Enrolled students and teaching staff by educational level of the formal school mode in the 2011/2012 and 2013-2014 school years in Mexico

\begin{tabular}{lcccc}
\hline \multirow{2}{*}{ Educational level } & \multicolumn{2}{c}{ Enrolled students (thousands) } & \multicolumn{2}{c}{ Teaching staff } \\
\cline { 2 - 5 } & 2011-2012 Cycle & 2013-2014 Cycle & 2011-2012 Cycle & 2013-2014 Cycle \\
\hline Preschool & $4,705.5$ & $4,787.0$ & 224,146 & 255,380 \\
Primary & $14,909.4$ & $14,580.4$ & 573,849 & 589,024 \\
Junior secondary & $6,167.4$ & $6,571.8$ & 388,769 & 394,947 \\
Career technical & 383.5 & 79.5 & 27,660 & 9,965 \\
High school & $3,950.1$ & $4,602.8$ & 258,314 & 371,657 \\
Higher and postgraduate & $3,161.2$ & $3,419.4$ & 342,269 & 349,193 \\
Total (approximate figures) & $33,200.0$ & $35,700.0$ & $1,850,000$ & $1,970,000$ \\
\hline
\end{tabular}

Source: INEGI (2012); INEE (2014); Presidencia de la República (2014).

Additionally, in the 2013-2014 school year, over 6 million students were taught in the non-school mode, mainly in adult education (52\%) and the open and semi-school system (22\%) (INEE, 2014).

Overall, public institutions in Mexico serve $84 \%$ of the student population, while private schools account for the remaining 16\% (Pereyra, 2008; INEE, 2014).

The Inter-American Development Bank (BID, 2012) reports that education in Mexico has made significant strides in recent decades. However, major challenges remain, including the following: 1) The education system is extremely big and the demographic structure places a great burden on it;2) There are still great challenges in terms of access and retention, particularly in the IE level; 3) There is low learning performance at all educational levels; 4) Equity remains a pending task for the State, since student access and learning are still determined by an individual's socio-economic background and geographical origin; 5) Achieving the goals of access and quality improvement requires more and better investment and a new funding framework.

Though the employment rate in Mexico is over 95\%, qualification mismatch is pervasive in the national job market. Consequently, companies face serious difficulties in finding talent. This phenomenon is due to young people and workers being ill-prepared for work. Furthermore, skill gaps may include a lack of generic or soft skills, namely team work, interpersonal skills, leadership, knowledge of foreign languages, readiness to learn, problem solving and ICT skills, among others (World Economic Forum, 2014; 2015).

The NES is very unequal. A considerable number of children and young people do not attend school, and those that lag behind the most and have the lowest academic performance are concentrated in areas of higher marginalization and lower income. There are great differences among Mexico's states in the educational path of their students. In the more marginalized states, the level of educational lag is much higher. Also, there is much disparity in educational results among states.

The average impact of socio-economic background on student performance is around the OECD average for students at age 15, but large performance and completion gaps persist, especially for indigenous and low socioeconomic status populations. According to Gegel et al. (2015), educational inequality is influenced by the 
nature of the educational systems of each country. Thus, system-level policies should focus on improving educational success of students from diverse backgrounds and delivering quality education across all schools, including upper secondary and vocational education and training. Raising the quality of teaching, improving the professionalization of school leaders, and providing transparency in governance and funding across the system are key issues.

The move toward making the IE level compulsory, emanating from the recent education reform, imposes new challenges on the system, because its set goal is to achieve full coverage in the 2021-2022 school year. In 2010 the IE level served 4.2 million students out of 6.3 million young people between 15 and 17 years old. Of the 2 million young people aged 15-17 who did not enroll in IE, approximately 800,000 were not eligible for consideration at this level for not having completed the previous level or for having dropped out at previous stages. In 2010, IE absorbed $96.4 \%$ of all students who completed junior high school in the immediately preceding cycle. In the 2009-2010 school year, 605,000 young people dropped out (more than 3000 per school day), of which more than $25 \%$ did so during the first year of IE (SEP, 2012).

Zepeda-Gil (2014) reported that only 1 in 10 children entering elementary school manages to finish studying a professional career due to a large number of obstacles, all related to social inequality and marginalization, which have to do with the multidimensional poverty in which about 53 million Mexicans live (Esquivel-Hernández, 2015). Of this population, 18 million are children. Furthermore, in educational terms, an estimated 8 million school-age young people have no access to education (Coordinadora Nacional de Trabajadores de la Educación [CNTE], 2013).

To reach the goals of reducing poverty and achieving equitable access to social rights, including education, it is necessary to strengthen the delivery of money transfers with other strategies that build productive opportunities for the population, and consolidate human development in its full dimension (Álvarez-Mendiola, 2014). In fact, the Mexican index of inequality between men and women is 0.376 , with 0 indicating greater equality and 1 greater inequality, which places Mexico $73^{\text {rd }}$ worldwide. Moreover, just $55.7 \%$ of women and $60.6 \%$ of men under the age of 25 have at least a high school education, and the average formal education in Mexico is 8.8 years for men and 8.1 years for women. Furthermore, the estimated earnings of women are less than half that of men, with $\$ 10,060$ per year compared to men's $\$ 22,020$ per year (Brundage, 2014; UNDP, 2015).

The UNDP (2014) has determined the human development index (HDI) in Mexico, based on three component indexes: health, education and income indexes. The analysis of gaps at the state level reveals the disparities that may exist within states, both in terms of the HDI and its component indexes. While there are states with homogeneous development levels (mainly Baja California), there are others where the situation is the exact opposite (Guerrero, Oaxaca, Chiapas, Veracruz and Chihuahua). In particular, the largest gap between municipalities is in the education dimension. That is, between the education index of Coicoyán de las Flores (0.207) and that of San Sebastián Tutla (0.910) in Oaxaca, there is a gap of $77.3 \%$, the highest in the country. However, it is noteworthy that the overall inequality in a state is not only explained by comparing municipalities with higher and lower performance. The distribution of the other municipalities is also important. Therefore, a detailed analysis of human development must take into account both factors (UNDP, 2014).

When individuals have a range of basic skills and opportunities, they are in a position to take advantage of many other options, both from citizen and government initiatives. Hence, the HDI is a powerful tool for bringing transparency to government management and knowing the impact that public policies have on the essential dimensions of human development, including education as the main determinant of the national HDI.

In Mexico, which has a land area of 1,964,375 km², at least 14 biogeographic regions and more than 120 million people with different traditions, cultures and principles, the panorama of human development is an extremely complex dimension. In 2010, the highest HDI value was 2.5 times greater than the lowest one, which indicates the marked inequality prevailing in the country in this area: in the municipalities with the greatest degree of development, the index value is similar to and even surpasses that of the richest and most prosperous nations in the world, while the municipalities that lag the furthest behind have similar conditions to those of today's poorest nations, and even to those existing in Mexico centuries ago (UNDP, 2014).

Zepeda-Gil (2014) explains that if you are born into a low-income family in an impoverished state, if you are indigenous, if you are a woman, if you have to work, if you do not have access to responsible sex education and contraceptives or you do not have the cultural capital for a standardized test, it is very unlikely that you will enroll in a university. In addition, the distance from home to the nearest school of any of the people who fall into these categories will be several kilometers, with no public transport available. Their schools will not offer all the years of courses they need and they will work in very poor conditions. In turn, teachers are not properly trained 
and lack the necessary tools to carry out their activities efficiently.

In Mexico, social capital building is in its infancy, and just a few studies have documented some initiatives (i.e. Rico García-Amado et al., 2012; Jones, Pollitt \& Bek, 2002). Importantly, communities with high levels of social capital, as evidenced by strong social networks, feelings of trust and safety and community participation, afford students access to supports, information, resources, and role models that can contribute to positive academic outcomes (Tennent et al., 2005). Consequently, the recent education reform may have a low impact on social capital building, especially for most people living in multidimensional poverty. Indeed, according to Alcántara-Saturnino and Marín-Fuentes (2013), the education reform imposed in Mexico suffers from a participatory construction. This fact demonstrates the erroneous processes followed by Mexican decision makers and politicians aimed at the construction of education reforms, which accounts for the lack of social cohesion that exists in the construction of governance in Mexico to date.

According to Esquivel-Hernández (2015) and taking into account the 2013 Education Census data, 48\% of public schools lack access to drainage, 31\% lack access to safe drinking water, $12.8 \%$ do not have bathrooms and $11.2 \%$ have no access to electricity. On the other hand, in $61.2 \%$ of them, students do not have access to a computer that works and $80 \%$ of students do not have Internet access. These students are therefore at a clear disadvantage compared to most private school students. Moreover, in some areas of Mexico public schools do not even have access to basic services such as electricity, drinking water, bathrooms or drainage, or infrastructure as basic as chairs, desks or blackboards. Hence, it is clear that those who study under these conditions face a critical disadvantage. The educational infrastructure, therefore, does not appear to contribute to the reduction of social inequality; on the contrary, it increases and perpetuates it. In fact, teacher salaries account for about $80 \%$ of education spending, leaving just $3 \%$ for investments in infrastructure (Organisation for Economic Co-operation and Development [OECD], 2015a).

The challenge is great, given the historical lags and the daunting task represented by the size of the population of children and youth estimated for 2014 at over 65.2 million (INEGI, 2014a), representing 54.3\% of the country's population.

While there has been progress in terms of coverage and the fact that the Mexican youth of today spend more time in school, much remains to be done. Mexico must ensure that its efforts, including the recent education reform, translate into real opportunities to improve the quality of education and access for all. And although the system is increasing its coverage, the large number of students should not be a factor that devalues the quality of teaching. Schools, administrators, teachers, students and parents need constant support. Indeed, despite the progress made in the last fifty years, Mexico still faces the challenge of reducing the development gap between its states and even more so among its municipalities, and urges solidifying efforts to address regional inequality.

According to the OECD (2014), in recent years, Mexico has devoted significant efforts and resources to advance the development of an inclusive, quality education system. In budgetary terms, Mexico invests more than $20 \%$ of total public spending on education, compared to the $13 \%$ average of OECD member countries (BID, 2012; OECD, 2012). Expenditure on education as a proportion of Gross Domestic Product (GDP) slightly increased from $5.0 \%$ in 2000 to $5.4 \%$ in 2012, which is comparable to that of the OECD average (i.e. 5.3\%). However, Mexican students have failed to attain the average grades of the member countries of this international organization, in math, reading or science, within the framework of the PISA, according to the last test applied in 2012 (OECD, 2012).

To compensate for these discrepancies in basic and intermediate education, the BID (2012) recommends three areas for immediate attention: Area 1: Quality, which requires improving student learning, that is, improvement in the percentage of students in the intermediate and advanced levels of national and international tests; Area 2: Coverage and Retention, which involves retaining and incorporating at least 3 million school-age children and young people into the system; and Area 3: Equity, which requires providing quality educational opportunities for 6.5 million children and young people living in indigenous and highly marginalized areas.

In its analysis, the OECD (2014) highlights the percentage of time that teachers spend imparting mathematics, natural sciences or Spanish, but does not even mention the creation or reaffirmation of values component, civic behavior, teamwork, personal development, entrepreneurship and innovation, which reflects the weakness of the Mexican educational system on the one hand, and of international educational assessment systems on the other.

Regarding postgraduate enrolment, the Asociación Nacional de Universidades e Instituciones de Educación Superior (ANUIES, 2013) reports that it reached 229,894 students in the 2011-2012 cycle, of which 110,105 were women (47.9\%) and 119,789 (52.1\%) were men. Of this enrolment, Mexico graduates over 36,000 new high-level professionals each year, in the following proportions: 12,265 new specialists, 20,793 new MSc 
holders and 3767 new doctors.

In terms of laying the groundwork for innovation, in addition to having solid basic and intermediate education levels, the most advanced nations have an efficient higher and postgraduate education system. And this is another of the great challenges facing Mexico. According to the Special Science, Technology and Innovation Program (Programa Especial de Ciencia, Tecnología e Innovación [PECiTI], 2014), in 2012, Mexico had 46,066 researchers with a doctoral or equivalent degree. In that year, the proportion of researchers in Mexico for every 1000 members of the Economically Active Population (EAP) was 0.9, a figure which is not only below those of advanced countries such as Sweden, with 9.8, or Japan, with 10.0, but many others, including some Latin American countries like Argentina, with 2.5 researchers per 1000 members of the EAP (Gómez-Merino, 2010). Accordingly, while Mexico graduates $4 \%$ of the new doctors of the OECD, Germany is graduating $12 \%$ and the United States $32 \%$ of the total number of new doctors within this organization (Benito-Bonito and Romera-Ayllón, 2014).

\section{The Science, Technology and Innovation System in Mexico}

According to the Science and Technology Act (STA; Cámara de Diputados, 2014b), the National Science, Technology and Innovation System (NSTIS) consolidates state policy in the conduct of scientific, technological and innovation activities, and promotes coordination and cooperation in the field. The NSTIS is composed of government, public policy and planning instruments, as well as a set of actors with different approaches and activities, which give it a unique complexity. Indeed, Solleiro, Aguilar \& Sánchez (2013) define the Mexican agri-food innovation system as complete, but at the same time complex, inefficient and ineffective, which could also be a valid description for the NSTIS. System actors include the public sector at its three levels (municipalities, states and federation), the academic and research sector, and the set of companies with STI activities. Currently, the National Science and Technology Council (CONACYT) serves as the coordinating and guiding body of the NSTIS.

\section{Current State of Innovation Indicators in Mexico}

Although great importance has been recently given to innovation in political discourse, the truth is that Mexico has much to improve to become a competitive economy. In terms of innovation, the World Economic Forum (2015) ranks Mexico $57^{\text {th }}$ of 140 countries surveyed (Table 3), when based on the size of its economy it should be in $14^{\text {th }}$ place. This low ranking is due to: a serious deterioration in the perception of how institutions function $\left(109^{\text {th }}\right.$ place); the quality of the education system, which has not had a positive impact on improving the knowledge and skills of young people required by the country (ranked $86^{\text {th }}$ ); and the low level of absorption of information and communication technologies ( $73^{\text {rd }}$ place), which is critical to innovation processes. Additionally, it has not been possible to realize the benefits of the most recent structural reforms aimed at increasing the level of market competition and functionality, which underscores the urgent need to implement these reforms effectively. If this reform implementation is achieved in the short term, Mexico can retain its strengths: its relative macroeconomic stability ( ranked $56^{\text {th }}$ ), its broad and deep domestic market that strengthens economies of scale (ranked $11^{\text {th }}$ ), its reasonably good transportation infrastructure (ranked 59 ), and its number of sophisticated businesses (ranked 50 $0^{\text {th }}$ ) (World Economic Forum, 2014; 2015). In spite of the implementation of a number of reformations in the labor market $\left(114^{\text {th }}\right)$, rigidities are still a problem, as are weak public $\left(115^{\text {th }}\right)$ and private $\left(78^{\text {th }}\right)$ institutions, with corruption being considered the most problematic factor for doing business (World Economic Forum, 2015). 
Table 3. Indicators determining innovation for Mexico according to the World Economic Forum (2014 and 2015).

\begin{tabular}{lcccc}
\hline \multirow{2}{*}{ Variables for measuring innovation } & \multicolumn{2}{c}{ Analysis 2014-2015 } & \multicolumn{2}{c}{ Analysis 2015-2016 } \\
\cline { 2 - 5 } & Score & Rank/144 & Score & Rank/140 \\
\hline Capacity for innovation & 3.7 & 72 & 4.0 & 66 \\
Quality of scientific research institutions & 3.9 & 58 & 4.1 & 47 \\
Company spending on research and development & 3.1 & 71 & 3.2 & 73 \\
University-industry collaboration in research and development & 4.0 & 44 & 4.0 & 43 \\
Government procurement of advanced tech products & 3.4 & 76 & 3.1 & 88 \\
Availability of scientists and engineers & 3.9 & 78 & 4.1 & 63 \\
PCT patents* & 1.8 & 58 & 4.1 & 63 \\
Average & 3.3 & 61 & 4.3 & 57 \\
\hline
\end{tabular}

Notes. This report provides an overview of the competitiveness performance of 144 economies (analysis 2014-2015) and 140 economies (analysis 2015-2016). Scores are on a 1-to-7 scale unless otherwise annotated with an asterisk $(*)$.

* PCT (Patent Cooperation Treaty) patents: applications/million population.

\subsection{Capacity for Innovation}

A country's capacity for innovation is measured by the attributes that companies have to innovate. The low value of this indicator (4.0; rank: 66/140) provides evidence of the poor performance of domestic firms to innovate and is a reflection of the physical, administrative and budgetary infrastructure available to underpin these approaches. As established by Solleiro, Aguilar, and Sánchez (2013), the complexity and inefficiency of the national innovation system is a significant constraint on national progress.

\subsection{Quality of Scientific Research Institutions}

The quality of the institutions that perform STI activities is an indicator of the relevance and impact of the substantive work carried out by institutes of higher education (IHE) and Public Research Centers (PRC) in terms of innovation. In the case of Mexico, this indicator is 4.1 (rank: 47/140) (World Economic Forum, 2015), which is reflected in the assessments of the impact of Mexican institutions worldwide, in which only the National Autonomous University of Mexico (UNAM) is among the top 500 universities in the world (Global Research University Profiles [GRUP], 2014).

\subsection{Company Spending on $R \& D$}

Business enterprise expenditure on R\&D is considered important for innovation and economic growth. It has frequently been used to compare countries' private-sector efforts on innovation. In Mexico, the contribution of the business sector to R\&D in 2014 was $40.1 \%$, while the government contributed $31.80 \%$, IHE $26.4 \%$ and the non-profit private sector $1.7 \%$ (Presidencia de la República, 2014). However, while for OECD countries, business R\&D accounts for $1.65 \%$ of GDP, in Mexico this barely reaches $0.3 \%$ of GDP (OECD, 2013a; Andrews \& Criscuolo, 2013). Hence, this indicator reaches only a value of 3.2 (rank: 73/140) according to the World Economic Forum (2015).

\subsection{University-Industry Collaboration in $R \& D$}

The national STI system has relatively strong links between IHE and PRC. By contrast, other links, such as those between IHE and PRC with the productive sector, are still low. Furthermore, due to the lack of dynamism of the domestic technology market, financial sector linkages with the productive sector are also in their infancy (PECiTI, 2014). In this category, the score for Mexico is 4.0 (rank: 43/140) (World Economic Forum, 2015).

\subsection{Government Procurement of Advanced Tech Products}

To address education challenges at its different levels, the Mexican government has implemented a range of reforms in recent years. To continue improving the whole education system, it will be necessary to consider the following issues: developing better qualified teachers; improving study programs; upgrading school infrastructure; overcoming critical equity challenges; improving education coverage and completion; implementing innovative teaching methodologies (Gutierrez, et al., 2015); progressing on accountability and focusing on improvement of student outcomes (Martin, 2009); increasing participation and balancing stakeholder autonomy at federal and state levels to generate inclusive governance (Santibañez et al., 2014); placing strong emphasis on staff and directing funding where it is most needed. The business and innovation environment pillar 
also measures the presence of conditions that allow innovation to flourish by including variables on the overall availability of technology, the demand conditions for innovative products, the availability of venture capital for financing innovation-related projects, and the presence of a skilled labour force (Bilbao-Osorio, Dutta \& Lavin, 2013). For Mexico, this variable has a value of 3.4 , which puts the country in $88^{\text {th }}$ place in global competitiveness (World Economic Forum, 2015).

\subsection{Availability of Scientists and Engineers}

Another important indicator of the support for innovation in countries is human capital, and in this area, Mexico has a rating of 4.1 (rank: 63/140) (World Economic Forum, 2015). Based on its EAP, estimated at over 50 million people, Mexico should have nearly 400,000 scientists and technologists, while the latest census reports that there are only just over 46,000 (PECiTI, 2014), which provides evidence of a great imbalance and leads to the low rating. As for engineers, while in Mexico 24,000 professionals graduate in this knowledge area per year, in the United States the figure is 60,000 annually, which shows the need to train more people in the engineering disciplines (Morán-Moguel \& Mayo-Hernández, 2013).

\subsection{PCT Patents}

In this area, Mexico has an activity level below expectations. In 2014, the proportion of patents applied for in Mexico by nationals stood at 8.4\% (1244 of 16,135 applications) (Instituto Mexicano de la Propiedad Industrial [IMPI], 2015). Moreover, the number of PCT patents granted to Mexicans in 2012 was only 192, compared to 17,105 for German and 42,779 for Japanese innovators (OECD, 2015b). According to the World Economic Forum (2015), Mexico has a rating of 1.9 (rank: 57/140).

\section{The Major Challenges for Innovation in Mexico}

To take advantage of the great benefits represented by innovation for economic progress and sustainable development, the Mexican government should focus its efforts on redressing the country's educational shortfalls and meeting social demands for a high-quality education system. As a major determinant of human development, education must indeed be the main focus of public policies aimed at improving the country's competitiveness. Education is, in fact, the main foundation of innovation and therefore of competitiveness and sustainable development.

With a high-quality education system, it is possible to lay the groundwork for the implementation of efficient public policies to support scientific research, technological development and innovation.

The importance of STI within the knowledge economy lies in the fact that its purpose is the creation of basic and applied knowledge; the latter aimed at the generation of innovative products and processes. To do this, funding sources may be the business sector, government, IHE themselves, private non-profit institutions and the external sector. The ratio of Gross Domestic Spending on STI to GDP is an international indicator used to measure current expenditure and investment allocated for these activities and reveals the degree to which a country's development is rooted in scientific and technological research. Developed countries spend on average between 1.5 and $3.8 \%$ of their gross domestic spending on R\&D (GDSRD). In 2014, Mexico's GDSRD accounted for $0.56 \%$ of GDP (PEF, 2014; Presidencia de la República, 2014). If the goal of allocating real increases on the order of $0.11 \%$ of GDP per year is met, the commitment to spend $1 \%$ of the overall budget on R\&D may be reached by 2018 . However, this percentage is still far below the OECD average ( $2.36 \%$ of GDP).

Of the total resources that the Mexican government gives to public domestic spending on R\&D, $96.4 \%$ comes from the federal government (central government and parastatal bodies) and only $3.6 \%$ from the state governments (Presidencia de la República, 2014).

As for infrastructure, while Mexico has high-quality laboratories and research centers, it does not have accurate inventories of them and their expansion takes place with no real planning of needs and capabilities.

Government and private support policies, which have been very limited, have been erratic and inefficient. For example, while in 2014, 500 positions were offered by CONACYT to young researchers, in 2015 only 250 are being offered (CONACYT, 2015). In addition, although the 2014-2018 PECiTI projects GDS on STI of 1\% GDP by 2018, for 2015, the federal spending budget saw a significant reduction for STI (Olivares-Alonso, 2015; Poy, 2015), which is evidence of the inconsistency between political discourse and practice.

A sustained effort has been made to strengthen the legal, regulatory and planning capability in the states of the Republic. In 2012, all states had an STA and a Science and Technology Council or the like; 25 of them had a Science and Technology Program and 20 a Commission on the matter in their local congresses. However, the structural framework remains highly volatile, and it is closely related to political movements within the states 
and the country as a whole. This has caused a great disparity in terms of STI capabilities among states.

With these strategies and commitments of government support, the highest development of STI capabilities was observed in Mexico City, followed by Nuevo León, Baja California Sur, Coahuila, Baja California and Sonora. The lowest development of such capabilities is shown in Campeche, Guerrero, Chiapas and Oaxaca, states which also show low HDI levels (Foro Consultivo Científico y Tecnológico [FCCyT], 2013).

As for highly-qualified human resources, in relative terms, in 2009, the graduation rate for new Ph.D. holders in OECD averaged 1.5, while in Mexico the rate was less than 0.4. The graduation rate for new Ph.D. holders is calculated as the number of new Ph.D. graduates per 1000 people between 25-34 years old (Benito-Bonito \& Romera-Ayllón, 2014).

Since the average number of scientists in OECD member countries is 7.5 for every 1000 members of the EAP, Mexico should have a population of 370,000 scientists, as its EAP is more than 52 million people (INEGI, 2014b). However, the country just has a little over 46,000 scientists, which affects scientific production, patent generation and the production of high-technology goods (HTG).

In the OECD analysis of the quantity and quality of scientific production for the period 2003-2011, Mexico is ranked $26^{\text {th }}$ of 40 countries (OECD, 2013b). As for the publication of scientific articles in prestigious journals, this indicator is still very low compared to the level attained by most other OECD member countries. In 2012 Mexico contributed $0.79 \%$ of the world's knowledge production, which is equivalent to less than a third of Brazil's contribution (PECiTI, 2014).

One deficient area requiring special and urgent attention is that most PRC and IHE have complex institutional regulations, with regard to the facilitation, streamlining, flexibility and promotion of linkage schemes that encourage the development and incubation of companies on the basis of their own researchers or institutions (PECiTI, 2014). But despite the complex legislation to access public resources, Mexico continues to suffer the scourge of corruption at all levels, placing $106^{\text {th }}$ of 177 countries surveyed, according to International Transparency (2014), which ranks the country as one of the most corrupt.

In this regard, Sánchez-Carranza (2013) shows that Mexico urgently needs to move towards fiscal accountability, taking innovation as a cross-cutting element, in at least the following areas: build trust and implement codes of ethics in government affairs; review the critical path of the General Law on Government Accounting; build a National Fiscal Control System in the three branches of government and the three levels of government; review the model of the National Anti-Corruption Commission; review the operation of the Law on Professional Career Service in the Federal Public Administration and enhance the professionalization of public servants.

This evolution should be dynamic yet flexible, simple, ingenious and practical. The attributes of modern public administration, related to openness, interaction and strategic planning, should also be applied to combat corruption. Innovation at the organizational level and preventive audits can play a major role in achieving this (Cabello \& Ortiz, 2013).

Within this area of competence, public administrators could play a crucial role in propelling ethical and efficient fiscal accountability, as well as in the development of preventive anti-corruption strategies, rather than evaluative and punitive ones.

In terms of business training in Mexico, support systems are under development. Innovative entrepreneurship is being promoted and the legal framework has been improved to facilitate the creation and expansion of businesses, but it lacks sufficient access to credit, especially at the business planning and creation stage.

The venture capital industry is still in its infancy in Mexico, accounting for only $0.02 \%$ of the country's GDP. Added to this, the lack of access to financing (seed capital, venture capital or providential investors) is one of the most significant barriers to the development of technology-based companies, especially in their earliest stages. While Mexico has policy instruments to encourage both entrepreneurial developments such as R\&D investment and linkage between the private and academic sectors operated by CONACYT and the Ministry of Economy, the funds are insufficient and the administrative processes related to the call for proposals, their evaluation and budget allocation are still deficient and take too long. Here, a constraint is also the lack of innovation experts to guide institutions and businesses, and to support evaluation and decision-making. Another challenge facing these programs, in addition to increasing investments, is to find counterparts in academia (IHE and PRC), since the small number of researchers hinders the operational practice of these initiatives because they don't have enough time to attend to them.

According to the National Council for Evaluation of Social Development Policies (Consejo Nacional de Evaluación de la Política de Desarrollo Social [CONEVAL], 2013), CONACYT faces three basic problems 
concerning STI: 1) low investment in science and innovation; 2) lack of knowledge translation strategies and platforms; and 3) lack of linkage between the activities of researchers belonging to the National System of Researchers and the different aspects they investigate. These issues are interrelated: the low investment in the sector does not allow the necessary impetus for scientific development and blocks the development of knowledge translation platforms. Another problem is the lack of a national scientific project registry platform to disseminate progress and results.

In its comprehensive assessment of the sector, CONEVAL (2014) also found that the generation of research, technological development and innovation is not enough to contribute to the country's economic and social development. The country's contribution to global knowledge production is less than $1 \%$ of the total; the number of Mexican researchers, for every 1000 members of the EAP, is about one-tenth of that in more developed countries and the number of Ph.D. graduates per million inhabitants (29.9) is insufficient to form human capital. In addition, the number of full-time researchers per 1000 inhabitants of the EAP in Mexico has been below the average for Latin America.

On the other hand, current public policies that should underpin innovation do not allow unlocking the country's potential as an emerging economy. For example, the GEA dismisses the importance of higher and graduate education, even though at these levels there is also a significant lag, since it is estimated that only $10 \%$ of students who enter elementary school manage to complete a university degree, and what it's even worse, only $0.01 \%$ of the student population achieves a doctoral degree (approximately 3500 of the 35 million students) (INEE, 2014). Given that innovation processes are closely related to educational levels and the number of scientists in a country, the need to promote graduate education to stimulate innovation processes is clear.

To generate innovations, the most advanced countries invest more than $1 \%$ of GDP on STI, and have highly-qualified professionals, both at the bachelor's degree and postgraduate level, educational levels that constitute the trigger for strengthening innovation indicators such as the generation of scientific knowledge, scientific publications, inventions and patents, among others. Although the Mexican government has made an effort to raise the educational level of its citizenry, by making it compulsory to take preschool, elementary, junior secondary (basic education) and senior secondary education, with these levels alone it would be very difficult to generate the innovations that the country requires, and demonstrates that State policy in terms of education, science, technology and innovation requires a more strategic and long-term vision in order to have a real impact on the country's progress. For this reason, in addition to establishing compulsory basic and intermediate education, it is necessary to establish a policy aimed at providing high-quality undergraduate and postgraduate training.

Due to important public administration moves such as the strengthening of IHE and PRC, in addition to the natural, genetic resource endowments and the demographic dividend represented by the bulge in working-age young people, Mexico has great potential to excel as a producer of high-tech goods (HTG). Foreign trade in HTG has shown great dynamism in recent years for our country; however, $83.3 \%$ of exports are carried out by maquiladoras, in which national technological content accounts for just a small fraction of its manufacturing. Although there are a considerable number of causes behind this, two of its determinants are the education level that has not empowered Mexicans, and the STI system, which has failed to generate relevant knowledge that can be converted into innovation and thus into HTG.

This weakness, partly caused by low production of HTG, is one of the reasons for the country's $72^{\text {nd }}$ ranking among 145 countries considered in the World Bank's Knowledge Economy Index (World Bank, 2012), which gives a clear account of the great challenges that must be overcome to move towards an economy that can base its growth on knowledge and innovation.

In most countries with developed economies, it is common for scientific generation, development and innovation processes to be intertwined, and no true borders can be distinguished among them. Industries carry out and fund a high percentage of STI projects in IHE and research institutes, and much of the science generated has practical purposes to solve specific problems or seize opportunities presented to nations, in addition to which basic knowledge has a high scientific impact. By contrast, in developing countries with emerging economies such as Mexico, these three approaches are separate, which is why the concept of linkage has been coined as a strategy for bringing together these components so that they interact with one another.

\section{Conclusions and Perspectives}

To address education challenges at its different levels, the Mexican government has implemented a range of reforms in recent years. To continue improving the whole education system, it will be necessary to consider the following issues: improving study programs and infrastructure at schools; overcoming critical equity challenges; 
improving education coverage and completion; implementing innovative teaching methodologies (Gutiérrez \& Villegas, 2015); progressing on accountability; focusing on improvement of student outcomes (Martin, 2009); increasing participation and balancing stakeholders autonomy at federal and state levels to generate inclusive governance (Santibañez et al., 2014); and placing strong emphasis on staff and directing funding where it is most needed.

To do this, an in-depth review of its current policies on education and STI is required. Parallel progress in the various human development indicators that show significant lag, including access to health, education and employment on the one hand, and STI generation on the other, will be needed. Given that education is a determinant of development, and hence of innovation, it is vital to take into account the national reality to propose public policies consistent with each need according to the regions and municipalities. From the early stages of the educational process, it may be possible to propose guidelines so that students understand the meaning and importance of innovation, as well as innovation generation and management processes. Thus, future innovation managers, at both the technical, political and administrative levels, must be trained on a very solid basis.

In addition, the data presented herein clearly shows the need to strengthen innovation indicators in order to seize "Mexico's Moment" (Kramer, 2014) and develop the skills required by the country to consolidate its sustainable economic development on the basis of a solid model of innovation. This strategy may allow Mexico to be ranked among the eight largest economies in the world by 2050, as predicted by various international agencies (Friedman, 2010; Goldman, 2010; PWC, 2011). Education, science, technology and innovation will be critical to achieve this goal.

\section{References}

Alcántara-Saturnino, A., \& Marín-Fuentes, V. (2013). Gobernanza, democracia y ciudadanía: sus implicaciones con la equidad y la cohesión social en América Latina. Revista Iberoamericana de Educación Superior 4, 93-112. Retrieved from http://www.scielo.org.mx/scielo.php?script=sci_arttext\&pid=S2007-287220130002 00007

Álvarez-Mendiola, R. (2014, August 14). Persiste desigualdad y marginación educativa: INEE. Educación Futura. Periodismo de Interés Público. Retrieved from http://www.educacionfutura.org/persiste-desigualdad-y-marginacion-educativa-inee/

Andrews, D., \& Criscuolo, C. (2013). Knowledge-Based Capital, Innovation and Resource Allocation. OECD Economics Department Working Papers No. 1046. http://dx.doi.org/10.1787/5k46bj546kzs-en

ANUIES. (2013). Anuarios Estadísticos de Educación Superior 2013. Versión 1.1. Asociación Nacional de Universidades e Instituciones de Educación Superior. México, D. F. Retrieved from http://www.anuies.mx/content.php?varSectionID=166

Benito-Bonito, M., \& Romera-Ayllón, R. (2014). La aportación de los doctores al desarrollo económico y social a través de su contribución a la $I+D+i$. Estudios CYD 05/2014. Fundación C y T. Barcelona, España. Retrieved from http://www.madrimasd.org/empleo/documentos/doc/Estudios-CYD5_La_aportacion_de_los _doctores_al_desarrollo_economico_social.pdf

BID. (2012). México: Retos para el Sistema Educativo 2012-2018. Banco Interamericano de Desarrollo. México, D. F. Retrieved from http://federalismoeducativo.cide.edu/documents/97536/36092cfa-7133-449f-be68-72d d4dd1d9d1

Bilbao-Osorio, B., Dutta, S., \& Lanvin, B. (2013). The Global Information Technology Report 2013, Growth and Jobs in a Hyperconnected World. World Economic Forum. Geneva, Switzerland. Retrieved from http://www3.weforum.org/docs/WEF_GITR_Report_2013.pdf

Brundage, R. (2014, August 3). Mexico Ranks Low in Education Level, Gender Equality, Health Spending, Public Security - UN Human Development Index. CNN Mexico. Retrieved from http://mexicovoices.blogspot.mx/2014/08/mexico-ranks-low-in-education-level.html

Cabello, A., \& Ortiz, E. (2013). Políticas públicas de innovación tecnológica y desarrollo: Teoría y propuesta de educación superior. Convergencia, 20, 135-172. Retrieved from http://www.redalyc.org/articulo.oa?id=10524674008

Cáceres-Reebs, D., \& Schneider. U. (2013). Vocational education and training in Mexico - how the country has tropicalised the dual model. BWP 5/2013. Retrieved from https://www.bibb.de/dokumente/pdf/BWP-Offprint_Pathways_to_an_attractive_VET_system.pdf 
Cámara de Diputados \& INEE. (2015). La Reforme Educativa. Marco Normativo. Retrieved from http://www.senado.gob.mx/comisiones/educacion/docs/docs_INEE/Reforma_Educativa_Marco_normativo. pdf

Cámara de Diputados. (2014a). Ley General de Educación. Última reforma del 20 de mayo de 2014. Retrieved from http://www.dipitados.gob.mx/LeyesBiblio/pdf/137.pdf

Cámara de Diputados. (2014b). Ley de Ciencia y Tecnología. Última reforma del 20 de mayo de 2014. Retrieved from. URL http://www.diputados.gob.mx/LeyesBiblio/pdf/242.pdf

CNTE. (2013). Análisis y perspectivas de la reforma educativa. Coordinadora Nacional de Trabajadores de la Educación. México, D. F. Retrieved from http://www.rebelion.org/docs/171157.pdf

CONACYT. (2015). Cátedras CONACYT: Convocatoria para Jóvenes Investigadores 2015. Retrieved from http://www.conacyt.mx/index.php/el-conacyt/convocatorias-y-resultados-conacyt/convocatoria-catedras/jov enes-2015

CONEVAL. (2013). Evaluación Integral del Consejo Nacional de Ciencia y Tecnología 2011-2012. Consejo Nacional de Evaluación de la Política de Desarrollo Social. Retrieved from http://www.coneval.gob.mx/Informes/Evaluacion/Integrales/Integrales\%202011-2012/EI_CONACYT.pdf

CONEVAL. (2014). Evaluación Integral del Desempeño de los Programas Federales de Investigación y Desarrollo Tecnológico 2012-2013. Consejo Nacional de Evaluación de la Política de Desarrollo Social. Retrieved from http://www.coneval.gob.mx/Informes/Evaluacion/Integrales/Integrales\%202012-2013/14 EI_DESARROLLO_TECNOLOGICO.pdf

Esquivel-Hernández, G. (2015). Desigualdad Extrema en México. Concentración del Poder Económico y Político. Oxfam, México. Mexico City. Retrieved from http://cambialasreglas.org/images/desigualdadextre ma_informe.pdf

FCCyT. (2013). Ranking Nacional de Ciencia, Tecnología e Innovación Capacidades y oportunidades de los Sistemas Estatales de CTI. Foro Consultivo Científico y Tecnológico. Retrieved from http://foroconsultivo.org.mx/libros_editados/ranking_2013.pdf

Friedman, G. (2010). The Next 100 Years: A Forecast for the 21st Century. Doubleday, New York, USA. Retrieved from http://www.mysearch.org.uk/website1/pdf/715.2.pdf

Gegel, L., Lebedeva, I., \& Frolova, Y. (2015). Social Inequality in Modern Higher Education. Procedia - Social and Behavioral Sciences, 214, 368-374. https://doi.org/10.1016/j.sbspro.2015.11.662

Goldman Sachs. (2010). Goldman Sachs' projection of the 20 largest economies in 2050. Retrieved from http://www.goldmansachs.com/mexico/

Gómez-Merino, F. C. (2010). Nuevas Tendencias Científicas y Tecnológicas en el Colegio de Postgraduados, Texcoco, Estado de México. Editorial Colegio de Postgraduados.

GRUP. (2014). 2014 Academic Ranking of World Universities. Retrieved from http://www.shanghairanking.com/

Gutiérrez, D., \& Villegas, E. G. (2015). The Importance of Teaching Methodology in Higher Education: A Critical Look. Procedia - Social and Behavioral Sciences, 174, 377-382. https://doi.org/10.1016/j.sbspro.2015.01.677

IMPI. (2015). IMPI en cifras 2015. Cifras 1993-enero/marzo 2015. Instituto Mexicano de la Propiedad Industrial. México, D. F. Retrieved from http://www.impi.gob.mx/QuienesSomos/ICIFRAS/IMPI_en_ CIFRAS_ene-mzo_2015.pdf

INEE. (2014). Panorama educativo de México: Indicadores del Sistema Educativo Nacional 2013. Instituto Nacional para la Evaluación de la Educación. Retrieved from http//www.inee.edu.mx/images/stories/2014/Home_PEM2013_OK010714.pdf

INEGI. (2012). México de un vistazo 2012. Instituto Nacional de Estadística y Geografía. Aguascalientes, México. Retrieved from http://www.inegi.org.mx/prod_serv/contenidos/espanol/bvinegi/productos/ integracion/pais/mexvista/2012/Mex_vi12.pdf

INEGI. (2014a). Estadísticas a propósito del Día Internacional de la Juventud. Instituto Nacional de Estadística y Geografía. Aguascalientes, México. Retrieved from http://www.inegi.org.mx/inegi/contenidos/espanol/ prensa/contenidos/estadisticas/2014/juventud0.pdf 
INEGI. (2014b). Resultados de la Encuesta Nacional de Ocupación y Empleo. Cifras durante el segundo trimestre de 2014. Boletín de prensa núm. 352/14. 13 de agosto de 2014. Aguascalientes, México. Retrieved from http://www.inegi.org.mx/inegi/contenidos/espanol/prensa/comunicados/estrucbol.pdf

International Transparency. (2014) Corruption Perception Index 2013. Retrieved from http://www.transparency.org/cpi2013/results

Jones, I., Pollitt, M., \& Bek, D. (2002). Multinationals in their communities: A social capital approach to corporate citizenship projects. ESRC Centre for Business Research, University of Cambridge Working Paper No. 249. Retrieved from http://www.cbr.cam.ac.uk/pdf/WP337.pdf

Kramer, K. (2014). Mexico's Moment in Davos. World Economic Forum. Davos, Switzerland. January 24, 2014. Retrieved from http://www.cnbc.com/id/101362188

Martin, C. (2009). Popular educational innovations in the hierarchical world of Mexican policy. International Journal of Educational Development, 29, 125-132. https://doi.org/10.1016/j.ijedudev.2008.09.006

Morán-Moguel, C. A., \& Mayo-Hernández, A. (2013). Panorama General del Empleo en Ingeniería. Academia de Ingeniería, A. C. Consejo Nacional de Ciencia y Tecnología. México, D. F. Retrieved from http://www.ai.org.mx/ai/images/sitio/edodelarte/2012/03.Panorama-general-del-empleo-en-ingenieria.pdf

OECD. (2012). México. Programa para la Evaluación Internacional de Alumnos (PISA). Retrieved from http://www.oecd.org/pisa/keyfindings/PISA-2012-results-mexico-ESP.pdf

OECD. (2013a). Knowledge-based Start-ups in Mexico. OECD Publishing. Paris, France. Retrieved http://www.oecd-ilibrary.org/industry-and-services/knowledge-based-start-ups-in-mexico_9789264193796en

OECD. (2013b). OECD Science, Technology and Industry Scoreboard 2013. Innovation for Growth. OECD Publishing. Paris, France. http://dx.doi.org/10.1787/sti_scoreboard-2013-en

OECD. (2014). México. Panorama de la Educación. Organización para la Cooperación y el Desarrollo Económicos. Retrieved from http://www.oecd.org/edu/Mexico-EAG2014-Country-Note-spanish.pdf

OECD. (2015a). Education at a Glance 2015. OECD Indicators. Retrieved from http://download.ei-ie.org/Docs/WebDepot/EaG2015_EN.pdf

OECD. (2015b). Patents by technology. Organization for Economic Cooperation and Development. Retrieved from https://stats.oecd.org/Index.aspx?DataSetCode=PATS_IPC

Olivares-Alonso, E. (2015). Manejable el recorte para ciencia; no impactará al CONACYT. Retrieved from http://www.jornada.unam.mx/2015/02/11/sociedad/037n2soc

PECiTI. (2014). Programa Especial de Ciencia, Tecnología e Innovación 2014-2018. Consejo Nacional de Ciencia y Tecnología. Retrieved from http://www.conacyt.mx/images/conacyt/PECiTI_2014-2018.pdf

PEF. (2014). Presupuesto de Egresos de la Federación para el Ejercicio Fiscal 2014. Retrieved from http://www.diputados.gob.mx/LeyesBiblio/pdf/PEF_2014.pdf.

Pereyra, A. (2008). La fragmentación de la oferta educativa en América Latina: La educación pública vs. La educación privada. Perfiles Educativos, 30, 132-146. Retrieved from http://www.scielo.org.mx/pdf/peredu/v30n120/v30n120a8.pdf

Poy, L. (2015). CONACYT reducirá a la mitad cátedras para investigadores. La Jornada. Retrieved from http://www.jornada.unam.mx/2015/01/23/sociedad/039n3soc

Presidencia de la República. (2014). Segundo Informe de Gobierno. Gobierno de los Estados Unidos Mexicanos. México, D. F. Retrieved from http://www.presidencia.gob.mx/segundoinforme/

PWC. (2011). El Mundo en 2050. El cambio acelerado del poder económico mundial: Desafíos y oportunidades. Retrieved from https://www.pwc.com.uy/es_UY/uy/publicaciones/assets/mundo-2050.pdf

Rico García-Amado, L., Ruiz Pérez, M., Iniesta-Arandia, I., Dahringer, G., Reyes, F., \& Barrasa S. (2012). Building ties: social capital network analysis of a forest community in a biosphere reserve in Chiapas, Mexico. Ecology and Society, 17, 3. https://doi.org/10.5751/ES-04855-170303

Sánchez-Carranza, G. (2013). Hacia una articulación de la rendición de cuentas en México. Revista de Administración Pública, 48, 39-59.

Santibañez, L., Abreu-Lastra, R., \& O’Donoghue J. L. (2014) School based management effects: Resources or 
governance change? Evidence from Mexico. Economics of Education Review, 39, 97-109. https://doi.org/10.1016/j.econedurev.2013.11.008

SEP .(2012). El Sistema Educativo de los Estados Unidos Mexicanos. Secretaría de Educación Pública. México, D. F. Retrieved from http://www.sep.gob.mx/work/models/sep1/Resource/1899/3/images/principales_cifras _2011_2012.pdf

Solleiro, J. L., Aguilar, J., \& Sánchez, L. G. (2013). Sistema de Innovación del Sector Agroalimentario. Retrieved from http://www.redinnovagro.in/documentosinnov/IICA\%20SNIA_M\%C3\%A9xico.pdf

Tennent, L., Tayler, C., Farrell, A., \& Patterson, C. (2005). Social Capital and Sense of Community: What do they mean for young children's success at school? In P. Jeffrey (Ed.), Proceedings Australian Association for Research in Education (AARE) International Education Research Conference (pp. 1-13). Sydney, Australia. Retrieved from http://eprints.qut.edu.au/2892/1/2892.pdf

UNDP. (2014). Índice de Desarrollo Humano Municipal en México: nueva metodología. Programa de las Naciones Unidas para el Desarrollo. México, D. F. Retrieved from http://www.undp.org.mx/desarrollohumano

UNDP. (2015). Human Development Report 2015. Work for Human Development. Retrieved from http://hdr.undp.org/sites/default/files/2015_human_development_report.pdf

World Bank. (2012). Knowledge Economy Index (KEI) 2012 Rankings. Retrieved from http://siteresources.worldbank.org/INTUNIKAM/Resources/2012.pdf

World Economic Forum. (2014). The Global Competitiveness Report 2014-2015. Davos, Switzerland. 548 p. Retrieved from http://www.weforum.org/reports/global-competitiveness-report-2014-2015

World Economic Forum. (2015). The Global Competitiveness Report 2015-2016. Davos, Switzerland. 403 p. Retrieved from http://www3.weforum.org/docs/gcr/2015-2016/Global_Competitiveness_Report_2015-2016. pdf

Zepeda-Gil, R. (2014). El desigual sistema educativo mexicano: Una carrera de obstáculos. Retrieved from http://www.paradigmas.mx/el-desigual-sistema-educativo-mexicano-una-carrera-de-obstaculos/

\section{Copyrights}

Copyright for this article is retained by the author(s), with first publication rights granted to the journal.

This is an open-access article distributed under the terms and conditions of the Creative Commons Attribution license (http://creativecommons.org/licenses/by/4.0/). 